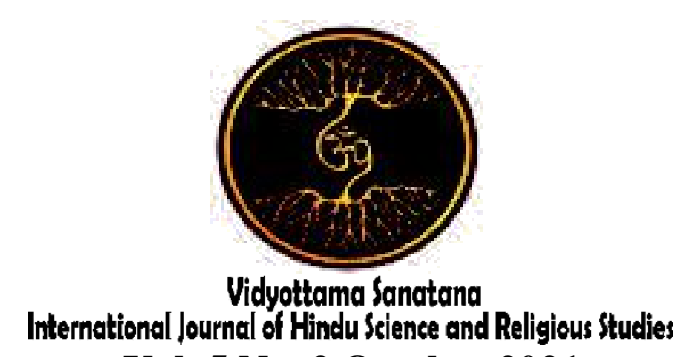

Vol. 5 No. 2 October 2021

\title{
RELIGIOUS HARMONY EDUCATION SYSTEM \\ IN EKASARI VILLAGE, JEMBRANA DISTRICT: \\ Overview of Sociology of Religious Education
}

\author{
By: \\ Ni Kadek Ayu Kristini Putri ${ }^{1}$, I Gusti Ngurah Sudiana ${ }^{2}$, I Nyoman Yoga Segara ${ }^{3}$ \\ 1,2,3 Universitas Hindu Negeri I Gusti Bagus Sugriwa Denpasar \\ E-mail: ${ }^{1}$ kadek.ayukristini27@gmail.com, ${ }^{2}$ ngurahsudiana@uhnsugriwa.ac.id, \\ 3yogasegara@uhnsugriwa.ac.id
}

\begin{tabular}{|l|l|l|}
\hline Received: May 17, 2021 & Accepted: May 19, 2021 & Published: October 31, 2021 \\
\hline
\end{tabular}

\begin{abstract}
Religious harmony in Indonesia and Bali was still a severe problem marked by the high potential for social conflicts with religious backgrounds. However, the people of Ekasari Village could maintain religious harmony in their area from generation to generation while at the same time providing space for every religious community to articulate their religious identity without pressure from other people. Religious harmony in Ekasari Village showed a strong relationship between education, social values, and religion. This study was conducted to analyze the education system for religious harmony in Ekasari Village from a sociological review of religious education based on the theory of structural functionalism, constructivism, and social action. The research was carried out by applying qualitative methods through observation, in-depth interviews, and document studies. The data were analyzed descriptivelyinterpretatively through three stages, namely data reduction, data presentation, and verification. This study found that the education system for religious harmony in Ekasari Village takes place in the realm of family, school, community, religious institutions, state, and civil society, as well as the mass media. This education system holistically encourages the internalization of knowledge, attitudes, and harmonious behaviour within religious communities.
\end{abstract}

Keywords: education, religion, harmony, sociology 


\section{INTRODUCTION}

Religious harmony is still a serious problem for the multi-religious Indonesian nation. The data shows that religious life in Indonesia has not yet fully achieved the expected ideal conditions, namely the realization of a religious society that is tolerant, harmonious and peaceful (Ismail, 2007:23). Social conflicts with religious dimensions still often occur and pose a latent threat that can occur at any time. One of them is shown by a survey by the Research and Development Agency of the Ministry of Religion of the Republic of Indonesia (2019) that the index of religious harmony in Indonesia is fluctuating. For example, in 2018, it was $70.90 \%$ (the 'good' category), but this figure was lower than 2017 at $72.27 \%$, and then rose again in 2019 to 73,83 .

Bali also has its challenges in building religious harmony. Although most of the Balinese population is Hindu, in Bali, other religious groups live to intermingle. Historically, relations between Hindus and other religious communities in Bali have been nurtured since the royal era through political, social, and economic interactions (Sukiada, 2007; Mashad, 2014; Irsyam, 2018). One of the phenomena of religious harmony in Bali, which is quite interesting to observe, is in Ekasari Village, Melaya District, Jembrana Regency. In this village, there are two large religious communities, namely Hindus and Catholics and a small number of Muslims and Protestants. Preliminary studies showed that so far, there has never been any inter-religious conflict in the village.

The people of Ekasari Village have succeeded in fostering religious harmony and have given freedom for every believer to articulate their religious and cultural identity. This phenomenon can be seen as the antithesis of Indonesia's general condition of religious harmony, which still shows the high potential for social conflict with religious backgrounds. The success of the Ekasari Village community in creating religious harmony was seen as inseparable from the existence of a value system that has a strong influence on people's lives. This is supported by Koentjaraningrat (2002) that the value system is the core of a culture built through the learning process. This value system shapes the mindset, attitudes, and behaviour of the community and is passed on between generations through the educational process. It means that the creation of religious harmony in Ekasari Village cannot be separated from the educational process as a medium for transforming the value system that takes place simultaneously and continuously.

The relationship between education, religious values, and social institutions, where individuals acquire and organize their experiences, is the main focus of studying the sociology of religious education (Idi, 2011). Education has a vital role in the socialization, internalization, and actualization of religious values in society. These religious values then also relate reciprocally to the function of social structures and institutions. Based on this relationship, this study focuses on the education system for religious harmony in Ekasari Village from a sociological review of religious education. Through this study, it can be revealed the role of the education system in building the values of religious harmony in Ekasari Village so that this study provides benefits, both theoretically and practically.

\section{METHODS}

This research was conducted qualitatively with an interpretive approach because the object studied was in the form of subjective values, knowledge, attitudes, and behaviour of the community, so that interpretation was needed to find its meaning. The study location is in Ekasari Village, Melaya District, Jembrana Regency. Data were collected through observation procedures, in-depth interviews, and document studies on various aspects related to religious harmony in Ekasari Village. Informants are determined purposively based on their 
position, authority, and capacity, namely traditional leaders, religious leaders, community leaders, citizens who represent every religious community, and religious and religious education staff.

Data analysis was carried out through three descriptive-qualitative research stages: data reduction, data presentation, and verification (Milles and Hubermen, 1987). According to Afifuddin and Saebani (2009), qualitative studies emphasize more on meaning because meaning is actual data, factual data, and describing the value behind everything that appears on the surface. The most important method for exploring the meaning of data is verstehen, namely interpretation and understanding. In this study, the verstehen method interprets the data by reflecting on previous theoretical ideas based on structuralfunctional theory, constructivism, and social action.

\section{RESULTS AND DISCUSSION}

Education functions as a mechanism for socializing and internalizing collective values to build order, order, and social balance in society (Maliki, 2010). This theory asserts that education must provide a mechanism for individuals to adapt to the environment and its changes for the realization of social integration and solidarity, as well as eliminating potential conflicts (Wirawan, 2010). Therefore, education must be carried out systematically and systematically by involving all elements in society. Vygotsky (in Budiningsih, 2005) emphasizes the importance of the interaction of the individual and the environment as a source of learning to construct meaningful knowledge. Based on this theory, the education system for religious harmony in Ekasari Village takes place in various domains that become sources of individual learning in socializing, internalizing, and equilibrating the values of religious harmony.

1. Education System in the Family
Education in the family requires the individual to understand how he should behave and behave based on the values instilled in the family. These values will colour the way of thinking and habits of life (Goode, 2004). Parents have roles and responsibilities in family education, significantly to shape the character and personality of children. In this case, the role of parents in teaching, instilling, and actualizing the values of religious harmony to children is an essential dimension of the education system in the family. In this regard, the education system for religious harmony in the family in Ekasari Village includes two integrated aspects: the role of parents and the function of family institutions.

The role of parents in teaching the value of religious harmony is closely related to parenting to build children's character and personality. Tarmudji (2004) states that parenting is the interaction between parents and children during the parenting period, namely educating, guiding, disciplining, and protecting children from reaching full maturity. The role of parents is to teach values and how to behave, both according to religious, moral, and social norms. In this regard, the role of parents in the education system for religious harmony in the family includes three things. First, being a role model of harmony for their children by showing the image of a family life that is always harmonious and peaceful. Second, showing examples of behaviour by the value of harmony, such as reprimanding children when fighting with their playmates. Third, giving freedom to children to get along with other people in their daily life so that they can foster the value of inter-religious harmony from an early age.

The role of parents is also supported by family institutions that function to regulate and control the actions of family members. Family institutions function to regulate all family members to carry out their respective functions and roles based on moral values (Hawari, 1997). In the 
context of religious harmony education in Ekasari Village, family institutions are mainly built based on the values of love, mutual help, and caring for one another. This institution is seen as effective in laying the foundation of harmony within each family member and being a medium for learning and cultivating the value of community harmony that can be developed in wider life.

\section{Education System in Schools}

School is the realm of formal education whose activities are regulated through regulations so that the educational process takes place in a directed and planned manner. Nevertheless, the education system provides flexibility for schools to develop an active and creative learning process through the interaction of teachers with students, fellow students, and students with their environment. Therefore, the education system for religious harmony in schools takes place in the realm of educational policies and curriculum and the actual learning process that takes place systemically.

Education policy in Indonesia refers to Law no. 20 of 2003 concerning the National Education System. Education held democratically and fairly and is not discriminatory by upholding human rights, religious values, cultural values, and national pluralism (Item 1) becomes the basic principle of education for religious harmony. In implementing education in schools, the functions, objectives, and principles of education are translated into the educational curriculum. If examined further, the education system for religious harmony in K-13 is packaged in a thematic that teaches students to recognize, respect, and appreciate religious differences and maintain inter-religious harmony. This curriculum plays a vital role in shaping students' cognitive and affective aspects of the importance of maintaining religious harmony.

The curriculum is developed through the creativity of teachers in actual learning. Based on the results of observations on educational activities at Swastisari Kindergarten, Niti Swadharma Kindergarten, Widyarini Kindergarten, SDN 1 Ekasari, SDN 2 Ekasari, Budi Rahayu Catholic Elementary School, SMP N 2 Melaya, and SMP Warna Murni, it was found that the actual learning model correlated with religious harmony education. , as follows (a) classical learning is still carried out based on the guidance of teaching materials by the 2013 curriculum (K-13); (b) before learning begins, the teacher begins to explore students' knowledge about the reality of religious differences in society; (c) the teacher asks students of different religions to sit together on one bench; (d) teachers say greetings of their religion and are often accompanied by greetings of other religions; (e) there is no discriminatory treatment against students of different religions throughout the learning process; and (f) the teacher conducts several activities outside of school (outdoor) to introduce students to places of worship for each religion.

The education system for religious harmony in schools that combines state regulations and teacher creativity in actual learning requires the assimilation, accommodation, and equilibration of student knowledge to take place holistically. Students can know the reality of religious differences at the cognitive level. Then at the affective level, students are also able to develop mutual respect and respect for religious differences and freedom of worship. In the end, students are also educated to be able to behave by the values of religious harmony at the psychomotor level. The integration of the three confirms that the education system for religious harmony in schools is in line with constructivism theory.

3. Education System in Society

Sociologically, society is the actual environment faced by each individual in his life. The education system in society is the arena of knowledge assimilation at the cognitive level, accommodation of attitudes at the affective level, and behavioural 
equilibration at the psychomotor level in collective life. Religious plurality is a social reality requiring that the education system for religious harmony in society takes place in (in) and through (by) a social system built by two essential elements: social structure and institutions. According to Ritzer (2003), social structure is a network of social relations in which social interactions are processed and organized and how individuals and subgroups can be distinguished. Meanwhile, social institutions are social orders that regulate the relationships between norms and values collectively.

The social structure in Ekasari Village is marked by the existence of social institutions or institutions that oversee the activities and interactions of its citizens. The hierarchical social structure includes administrative and regional institutions, namely the official Banjar (hamlet) and the official village, which houses residents of all religions. In addition, there is also a social structure based on traditional and religious ties, namely the traditional Banjar and traditional villages, which specifically only consist of Hindus. Within these institutions, other social organizations were found as part of a larger structure, such as Karang Taruna in the official village structure and Sekaa cadets in the traditional village structure. There is a subak institution in the professional realm that houses farmers, and its members come from all religions. All of these institutions are sources of community learning in building religious harmony.

The most important lesson from a social structure is positioning individuals according to their authority, role, and function in society to create social order and balance. The individual's position in the social structure is the completeness of the social system in an organizational society (Ritzer, 2003; Wirawan, 2012). In the context of religious harmony in Ekasari Village, the social structure is a driver of public order and peace. To realize this social balance, the fulfilment of the rights of citizens in a just manner and the implementation of the obligations of every citizen is the responsibility of the social structure to control it. The reciprocal relationship between structure and social obligations that citizens must carry out builds a functional, structural relationship between the two. The local political process in the election of village heads is a form of learning that every religious community has equal rights to fill positions in a democratic social structure.

Awareness of religious harmony in Ekasari Village is also supported by cultural and spiritual values that underlie the community's social institutions. Social institutions built through the institutionalization of habits and collective behaviour are proven to foster a sense of togetherness (sense of collectivity), a self of belonging, and a sense of freedom as citizens. In this case, several values were found that became a source of community learning to build harmony, including (a) the use of Balinese as a medium of daily communication has been institutionalized in the social life of the people in Ekasari Village; (b) the custom of pasilihsihan, namely visiting each other and making material contributions to residents who carry out joy or sorrow activities; and (c) cooperation activities in various individual and social activities.

The role of social structures and institutions in the education of religious harmony in society is in line with Vygotsky's opinion (in Maliki, 2010) that in a constructivist perspective, socio-cultural activities play an essential role in building individual cognitive, affective, and psychomotor development through the process of assimilation, accommodation, and continuous equilibration. Through social structures and institutions, individuals assimilate new knowledge with previous knowledge. Social life encourages the process of accommodation through a cognitive adjustment to real situations. Furthermore, equilibration occurs when individual knowledge promotes the growth 
of mental stability, namely not feeling alienated from the social world.

\section{Education System in Religious Institutions}

The education system for religious harmony in religious institutions is closely related to individual religious beliefs and understandings as an intrinsic dimension of religious awareness. Mahzar (in Kahmad, 2002) states that religious education must keep religious people away from absolutism, exclusivism, fanaticism, extremism, and aggressiveness that can weaken the spirit of religious harmony. To build religious attitudes that are inclusive, tolerant, and respect religious differences, religious institutions have an essential role in it. Considering that religious institutions are social institutions that are responsible and authorized in the development of dogma, worship, and religious morals for their people (Hardjana, 2005).

Three religious institutions have the most influence on the lives of religious people in Ekasari Village, namely the Traditional Villages (Palalinggah and Ekasari), which regulate the religious order of Hindus; The Parish of the Sacred Heart of Jesus Palasari, which controls the religious order of the Catholics; and the Takmir of the Baitul Muslimin Mosque which regulates the religious order of Muslims. Religious guidance and development to their respective followers is a vital function of the three institutions. Findings in the field indicate that religious institutions in Ekasari Village have an essential role in building religious awareness. Internal religious guidance is carried out to strengthen the faith and worship obedience of each of its people. However, in the coaching process, religious understanding and inclusive and tolerant attitudes are also instilled in other religious communities. So, the education system for religious harmony in religious institutions targets the development of faith and piety among people of the same religion and the formation of religious attitudes in responding to religious plurality.
5. The Role of the State and Civil Society

The 1945 Constitution of the Republic of Indonesia mandates that the state guarantees religious freedom for all citizens, including efforts to create religious harmony. The role of the state in fostering religious harmony is present in the form of legislation and the Ministry of Religion, which is responsible for regulating religious life. The latest regulations that regulate religious harmony are the Joint Regulation of the Minister of Religion Number 9 of 2006 and the Minister of Home Affairs Number 8 of 2006 concerning Guidelines for the Implementation of the Duties of Regional Heads/Deputy Regional Heads in Maintaining Religious Harmony, Empowerment of Religious Harmony Forums, and Establishment of Houses of Worship (abbreviated PBM No. 9 and 8 of 2006). In principle, this PBM emphasizes the involvement of local governments in the context of maintaining religious harmony, empowering religious harmony forums, and establishing houses of worship by the spirit of regional autonomy. This regulation has also been socialized to the public, especially through religious leaders in one of the Ministry of Religion of Jembrana Regency activities.

Religious harmony through increased participation and the role of civil society is equally essential. Prasetyo et al. (2008:5) state that civil society is a public space to develop freedom, equality, and values related to autonomy, volunteerism, and balance. In the development of religious harmony, civil society plays a vital role in building a multicultural society, namely cultivating the plurality of society so that it remains stable, cohesive, alive, and comfortable. Several roles of civil society to realize these conditions include (a) encouraging the creation of a complementary relationship intensity between the community and the state; (b) guarantee the fulfilment of citizens' constitutional rights in justice and equality before the law; (c) encouraging the seeding 
and movement of critical intellectual traditions; (d) cultural development based on multiculturalism; (e) build multicultural awareness in society; and (f) strengthening plural and inclusive collective identities. Through the role of the state and civil society, religious harmony in Ekasari Village shows a collective identity as a multicultural society.

6. The Role of Mass Media

Mass media, especially digital media, have a significant role in the education system for religious harmony in Ekasari Village. The majority of the people of Ekasari Village are used to accessing information from the internet and other mass media. Mass media has no structural boundaries because information technology reaches all levels of society regardless of age, region, social, cultural, and religious boundaries. Boudrillard (1999:3) states that reality has merged into one where signs, images, and models are no longer possible to find explicit references. This fact indicates that individual religious understanding, especially religious harmony, is also built by information that society absorbs from virtual media. This confirms that digital media has taken on a role as the realm of public education because the information presented is a reference for individuals or groups in building their religious knowledge.

One of the negative impacts in the religious field that can be born from internet information is radicalism and religious exclusivism. This ideology indeed endangers religious harmony with the emergence of hatred against other religious groups. Moreover, the fact shows that religious discourses with exclusive and radical nuances are widely circulated in the internet media. This impact is also realized by the people of Ekasari Village. Filtering the variety of information presented is a determinant of the success of the learning process for religious harmony. Based on constructivism theory (Maliki, 2005), it can be understood that the ability to sort and select useful information is closely related to previous knowledge so that there is a continuous equilibration. That is, an individual's understanding of religious information through the internet, of course, also involves knowledge obtained from other educational institutions. The accumulation of knowledge and experience form a selective attitude towards information on the internet.

\section{CONCLUSION}

This study concludes that the education system for religious harmony in Ekasari Village from a sociological review of religious education takes place in various learning sources. The education system in the family involves two elements, namely the role of parents and the function of family institutions. The education system for religious harmony in schools involves elements of state regulation and creativity in actual learning. The education system for religious harmony in society takes place within and through social structures and institutions. The education system for religious harmony in religious institutions through internal and external spiritual development. The role of the state and civil society in the education system for religious harmony is complementary. The role of the mass media is to become a source of religious information that is inclusive and tolerant through dialectic selection.

\section{REFERENCES}

Afifuddin, H, dan Beni Ahmad Saebani. 2009. Qualitative Research Methodology. Bandung: Faithful Library.

Baudrillard, J. 1999. Simulacra and Simulation (Translated by Sheila Faria Glaser). Ann Arbor: The University of Michigan Press.

Budiningsih, C. Asri. 2005. Moral Learning, Based on the Characteristics of Students and Their Culture. Jakarta: Rineka Cipta. 
Goode, W. J. 2004. Family sociology. Jakarta: Publisher PT Bumi Aksara.

Hardjana. 2005. Agama, Religiusitas, dan Spiritualitas. Bandung. Tarsito.

Idi, Abdullah. 2011. Sociology of Education: Individuals, Society, and Education.Jakarta: Rajawali Press.

Irsyam, Tri Wahyuning M. 2018. "Christianization on the Island of the Gods in the Dutch Colonial Era”. Jurnal Sejarah Citra Lekha, Vol.3, No. 1., 2018, hal. 43-57.

Ismail, Ariffudin. 2010. "Reflection on Patterns of Religious Harmony: Religious Phenomena in Central Java, Bali, and West Kalimantan". Jurnal Analisa Vol. XVII. No. 02, Juli-Desember, 2010, hal. 175186.

Ismail, Faisal. 2007. The dynamics of interreligious harmony. Bandung: Remaja Rosdakarya.

Kahmad, Dadang. 2002. Sosiologi Agama. Bandung: Remaja Rosdakarya.

Koentjaraningrat. 2002. Culture, Mentality and Development. Jakarta: Gramedia Pustaka Utama.

Maliki, Zainuddin. 2010. Sosiologi Pendidikan. Yogyakarta: UGM.

Mashad. Dhurorudin. 2014. Balinese Muslims Search for Lost Harmony. Jakarta. Puataka-Al Kautsar

Miles, Mathiew B. dan Michael Huberman. 1992. Qualitative Data Analysis. Jakarta: Universita Indonesia.

Parekh, Bhiku. 2007. Rethinking Multiculturalism Cultural Diversity and Political Theory. Yogyakarta: Kanisius.

Prasetyo, Hendro, dkk. 2008. Islam \& Civil Society Pandangan Muslim Indonesia. Jakarta: Gramedia Pustaka Utama bekerjasama dengan PPIM-IAIN Jakarta.

Ritzer, George. 2003. Sociology of Science with a Dual Paradigm. Jakarta: Rajawali Press.
Sukiada, I Nyoman. 2007. The Role of Local History in Building Multiculturalism in Indonesia". Jurnal Ilmiah Dharma Smerti, Edisi April 2007, hal. 20-29.

Syaukani, Imam. 2008. Complications of Religious Harmony Policies and Legislations. Jakarta: Pusat Penelitian dan Pengembangan Kementerian Agama RI.

Tarmudji, T. 2004. Research on "The relationship between parenting styles and adolescent aggressiveness"'. http://www.dep.dik.nas/go.id.

Undang-undang Nomor 20 Tahun 2003 tentang Sistem Pendidikan Nasional.

Wirawan, Ida Bagus. 2012. Social Theories in Three Paradigms: Social Facts, Social Definitions, \& Social Behavior. Jakarta: Prenada Media. 